\section{Correction: Activation of aryl hydrocarbon receptor signaling by a novel agonist ameliorates autoimmune encephalomyelitis}

\section{The PLOS ONE Staff}

The authors' given names and surnames are switched. The correct names are: Abdullah Alzahrani, Maged Mohammed, Hairul-Islam M. Ibrahim, Osama I. Alwassil, Maha Habash, Manal Alfuwaires, Hamza Hanieh. The correct citation is: Alzahrani A, Mohammed M, Ibrahim HM, Alwassil OI, Habash M, Alfuwaires M, et al. (2019) Activation of aryl hydrocarbon receptor signaling by a novel agonist ameliorates autoimmune encephalomyelitis. PLoS ONE 14(4): e0215981.https://doi.org/10.1371/journal.pone.0215981. The publisher apologizes for the errors.

\section{Reference}

1. Abdullah A, Maged M, Hairul-Islam M. I, Osama I. A, Maha H, Manal A, et al. (2019) Activation of aryl hydrocarbon receptor signaling by a novel agonist ameliorates autoimmune encephalomyelitis. PLoS ONE 14(4): e0215981. https://doi.org/10.1371/journal.pone.0215981 PMID: 31026283

\section{G openaccess}

Citation: The PLOS ONE Staff (2019) Correction: Activation of aryl hydrocarbon receptor signaling by a novel agonist ameliorates autoimmune encephalomyelitis. PLOS ONE 14(10): e0223429. https://doi.org/10.1371/journal. pone.0223429

Published: October 10, 2019

Copyright: ๑ 2019 The PLOS ONE Staff. This is an open access article distributed under the terms of the Creative Commons Attribution License, which permits unrestricted use, distribution, and reproduction in any medium, provided the original author and source are credited. 